\title{
PENINGKATAN KEAMANAN PANGAN DAN KUALITAS ORGANOLEPTIK IKAN ASAP KHAS DESA KARANGSARI TUBAN MELALUI INDUKSI PENGEMAS VAKUM
}

\author{
Rahmi Nurdiani ${ }^{12^{*}}$, Abdul Aziz Jaziri ${ }^{1,2}$, Yoga Dwi Jatmiko ${ }^{3}$ \\ ${ }^{1}$ Program Studi Teknologi Hasil Perikanan, Fakultas Perikanan an Ilmu Kelautan, Universitas Brawijaya \\ ${ }^{2}$ Bioseafood Research Group, Fakultas Perikanan dan Ilmu Kelautan, Universitas Brawijaya \\ ${ }^{3}$ Jurusan Biologi, Fakultas Matematika dan Ilmu Pengetahuan Alam, Universitas Brawijaya
}

*Koresponden penulis: rahmi_nurdiani@ub.ac.id

\begin{abstract}
Abstrak
Produksi ikan asap di Kabupaten Tuban tumbuh secara signifikan karena lokasi penjualannya dekat lokasi wisata. Salah satu kawasan penghasil ikan asap ini beradadi Desa Karangsari, Tuban. Permasalahan keamanan pangan masih belum diperhatikan oleh para produsen ikan asap yang terlihat dari tampilan produk dalam keranjang terbuka dan pengemasan yang seadanya. Hal ini mempengaruhi daya simpan produk yang hanya bertahan 1-2 hari. Oleh karena itu, penelitian ini bertujuan untuk meningkatkan kualitas produk ikan asap (mikrobiologi dan organoleptik) melalui induksi teknologi pengemasan vakum pada kelompok usaha pengasapan ikan. Metode pengujian sampel menggunakan metode Total Plate Count (TPC) untuk mengukur jumlah bakteri pada sampel dan Uji Hedonik untuk menentukan tingkat kesukaan terhadap sampel ikan asap. Hasil uji TPC menunjukkan pada sampel ikan asap pada suhu ruang memiliki nilai TPC sebesar 3,50 x $10^{6} \mathrm{CFU} / \mathrm{gr}$, sedangkan pada suhu dingin dan beku nilai TPC adalah $0 \mathrm{CFU} / \mathrm{gr}$. Hasil uji hedonik menunjukkan tingkat kesukaan panelis paling tinggi pada produk ikan asap terdapat pada perlakuan sampel yang dikemas vakum dan di bekukan dengan nilai organoleptik dari skala kenampakan 8,2 ; bau 8,2; rasa 7,46; dan tekstur 7,66. Kombinasi antara pengemasan vakum dan penyimpanan pada suhu dingin dan beku dapat menghambat pertumbuhan bakteri secara optimal. Dilihat dari hasil uji TPC menunjukkan penyimpanan pada produk ikan asap dengan dikemas vakum dan di bekukan memiliki masa simpan sampai hari ke 30. Pengemasan vakum terbukti dapat mempertahankan kualitas dan meningkatkan keamanan pangan produk ikan asap tradisional khas Tuban.
\end{abstract}

Kata Kunci: Ikan asap, kemasan vakum, total bakteri, kualitas, Tuban

\begin{abstract}
Production of smoked fish in the Tuban Regency has grown significantly because of its high demand, and the sale location is near tourist sites. One of Tuban smoked fish producer areas is in Karangsari Village, Tuban. The issue of food safety was not being considered by the smoked fish producers, as the smoked fish were always kept in an uncovered basket with minimal packaging. This condition affected the shelf-life of the products, which only lasted for 1-2 days. The sample testing method used was the Total Plate Count (TPC) and Hedonic Test methods to determine the total of bacteria on the samples and the level of consumer preference for smoked fish samples, respectively. The results of TPC showed that smoked fish stored at room temperature had a TPC value of $3.50 \times 106 \mathrm{CFU} / \mathrm{gr}$, while at cold and frozen temperatures, the TPC value was $0 \mathrm{CFU} / \mathrm{gr}$. A higher preference of panelists was observed on the vacuum-packed samples and frozen with organoleptic values of appearance 8.2; odor 8.2; taste 7.46; and texture 7.66. The combination of vacuum packaging and storage in cold and freezing temperatures could inhibit bacterial growth optimally. It was suggested that vacuum-package and frozen smoked fish had a shelf life until 30 days.
\end{abstract}

Keywords: Smoked fish, vacuum packaging, total bacteria, quality, Tuban

\section{PENDAHULUAN}

Jawa Timur termasuk pemasok hasil perikanan terbesar di Indonesia. Produksi ikan di Jawa Timur mencapai 1,6 juta ton pada
2017, yang terdiri dari produksi perikanan budidaya sebesar 1.189.594 ton dan produksi perikanan tangkap sebesar 427.459 ton [1]. Salah satu kabupaten dengan potensi perikanan yang cukup besar adalah Tuban. 
Produksi perikanan di Tuban mencapai 59.168 ton pada 2017, yang terdiri dari produksi perikanan budidaya sebesar 42.351 ton dan perikanan tangkap sebesar 16.817 ton [2]. Selain itu, untuk menunjang kegiatan perikanannya, Tuban memiliki lima Tempat Pelelangan Ikan (TPI), satu Pelabuhan Nusantara, dan satu sentra penjualan produk ikan yang bernama Plaza Ikan Tuban.

Produk ikan asap di Desa Karangsari, Tuban, merupakan komoditas andalan dan menjadi daya tarik bagi wisatawan sehingga penting bagi perekonomian di Tuban. Pada umumnya para penjual ikan asap tersebut adalah istri-istri para nelayan yang bermukim di pinggir pantai Tuban. Proses pembuatan ikan asap masih menggunakan tungku asap yang proses produksinya berlangsung 30-60 menit tergantung pada ukuran dan jumlah ikannya. Tungku tersebut dilengkapi dengan cerobong asap yang berfungsi sebagai aliran angin sehingga proses pengasapannya dapat berlangsung dengan cepat. Ikan asap yang dihasilkan memiliki tekstur padat, berwarna coklat dan beraroma asap karena ikan yang dipakai masih dalam kondisi segar. Produk ikan asap ini memiliki masa simpan 1-2 hari, sebagaimana Mareta dan Awami [3] dan Tutuarima [4] menyatakan bahwa produk ikan asap hanya mampu bertahan 1-2 hari.

Ikan asap khas Tuban sangat digemari oleh konsumen karena memiliki aroma khas, teksturnya padat, rasanya yang enak, dan harganya terjangkau. Namun, sebagian besar konsumen masih mengeluhkan masalah tampilan (display) produk dan pengemasannya. Ikan asap biasanya hanya diletakkan pada keranjang tanpa ditutup, sehingga tidak jarang lalat hinggap di ikan asapnya. Selain itu, kemasan produknya hanya menggunakan kertas minyak, daun jati, dan bahkan kertas koran. Kedua permasalahan ini harus dipecahkan melalui perbaikan pengemasan, dan tampilan produk. Masalah prioritas ini menjadi penting untuk segera diselesaikan guna meningkatkan pencapaian daya saing perekonomian yang didukung dengan penerapan IPTEK.

\section{BAHAN DAN METODE}

\section{Tempat dan Waktu}

Kajian ini dilaksanakan di Desa Karangsari, Kecamatan Tuban, Kabupaten
Tuban pada bulan Juni sampai Nopember 2019. Analisis mikrobiologi dilakukan di Laboratorium Keamanan Hasil Perikanan, Fakultas Perikanan dan Ilmu Kelautan, Universitas Brawijaya.

\section{Teknologi Pengemasan Vakum}

Teknologi pengemasan ikan asap menggunakan kemasan vakum tipe Astro DZ 280 SE.

\section{Uji Kualitas Mikrobiologi}

Jenis ikan yang digunakan adalah ikan kembung yang diperoleh dari perairan sekitar Desa Karangsari. Ikan asap kemasan vakum dan tidak dikemas dibagi menjadi tiga perlakuan penyimpanan yaitu disimpan pada suhu ruang $\left(27^{\circ} \mathrm{C}\right)$ pada hari ke-0, 1, 2, 3, dan 4 , suhu dingin $\left(4^{\circ} \mathrm{C}\right)$ pada hari ke- $0,2,4$, dan 6 , serta suhu beku $\left(-20^{\circ} \mathrm{C}\right)$ pada hari ke- 0,15 , dan 30. Kualitas mikrobiologi dari tiap sampel diuji menggunakan metode Total Plate Count (TPC). Sampel sebanyak $10 \mathrm{~g}$ dimasukkan ke dalam $90 \mathrm{~mL}$ larutan garam fisiologis $(0,85 \%$ $\mathrm{NaCl})$. Suspensi sampel sebanyak $1 \mathrm{~mL}$ kemudian diencerkan secara bertingkat pada 9 $\mathrm{mL}$ larutan garam fisiologis $(0,85 \% \mathrm{NaCl})$ hingga diperoleh dilusi 10-4. Setiap hasil pengenceran berseri kemudian diambil sebanyak $0,1 \mathrm{~mL}$ lalu di-platting pada media Nutrient Agar, dan diinkubasi pada suhu $37^{\circ} \mathrm{C}$ selama $24-48$ jam.

Total bakteri hasil TPC dalam daging ikan asap merupakan salah satu parameter mikrobiologis yang digunakan untuk menentukan tingkat kemunduran mutu ikan asap [5]. Berdasarkan SNI 2725.1-2009 [6], ikan asap memiliki persyaratan mutu dan keamanan pangan yang harus diperhatikan. Persyaratan mutu dan keamanan pangan ikan asap dapat dilihat pada Tabel 1.

Tabel 1. Persyaratan Mutu dan Keamanan Pangan

\begin{tabular}{|c|c|c|}
\hline Jenis Uji & Satuan & Persyaratan \\
\hline $\begin{array}{l}\text { a. Organoleptik } \\
\text { b. Cemaran Mikroba* }\end{array}$ & Angka (1-9) & Minimal 7 \\
\hline$-\mathrm{ALT}$ & Koloni/g & $\begin{array}{l}\text { Maksimal } 1,0 \\
\times 10^{5}\end{array}$ \\
\hline - Eschericia coli* & APM/g & Maksimal < 3 \\
\hline - Salmonella* & Per $25 \mathrm{~g}$ & Negatif \\
\hline - Vibrio cholerae* & Per $25 \mathrm{~g}$ & Negatif \\
\hline - Staphylococcus aureus* & Koloni/g & $\begin{array}{l}\text { Maksimal } 1,0 \\
\text { x } 103\end{array}$ \\
\hline \multicolumn{3}{|l|}{ c. Kimia } \\
\hline - Kadar air & $\%$ fraksi massa & Maksimal 60 \\
\hline - Kadar histamin & $\mathrm{mg} / \mathrm{kg}$ & Maksimal 100 \\
\hline - Kadar garam & $\%$ fraksi massa & Maksimal 4 \\
\hline CATATAN *) Bila diperl & & \\
\hline
\end{tabular}




\section{Uji Kualitas Organoleptik}

Pengujian organoleptik pada sampel ikan asap baik yang dikemas vakum maupun yang tidak dikemas dilakukan berdasarkan parameter kenampakan, bau, rasa, dan tekstur dengan masing-masing parameter dinilai dengan skala 1-9. Semakin tinggi nilai pada uji organoleptik maka semakin tinggi penerimaan panelis terhadap ikan asap yang diujikan.

\section{HASIL DAN PEMBAHASAN}

\section{Uji Kualitas Mikrobiologi (Total Bakteri)}

Pengujian TPC menunjukkan bahwa penggunaan kemasan vakum dapat membantu mengurangi jumlah bakteri pada produk ikan asap sebagaimana terlihat pada Tabel 2 dan Gambar 1. Selain kemasan vakum, proses penyimpanan juga dapat menurunkan total bakteri. Pada sampel VD (kemasan vakum disimpan pada suhu dingin) dan VB (kemasan vakum disimpan pada suhu beku) menunjukkan nilai 0 pada hasil TPC. Bila dibandingkan dengan kriteria SNI No. 2725.1 tahun 2009 tentang ikan asap yaitu dengan jumlah maksimum $50 \times 10^{4} \mathrm{cfu} / \mathrm{g}$, maka ratarata nilai TPC pada sampel ikan asap yang tidak dikemas vakum sudah tidak layak untuk dikonsumsi.

Tabel 2. Nilai TPC pada sampel ikan asap dengan kemasan vakum dan tanpa dikemas vakum

\begin{tabular}{lccc}
\hline Kemasan & $\begin{array}{c}\text { Suhu Ruang } \\
\left(27^{\circ} \mathbf{C}\right)(\text { Hari } \\
\text { ke 4) }\end{array}$ & $\begin{array}{c}\text { Suhu Dingin } \\
\left(4^{\circ} \mathbf{C}\right)(\text { Hari } \\
\text { ke 6) }\end{array}$ & $\begin{array}{c}\text { Suhu Beku } \\
\left(-20^{\circ} \mathbf{C}\right)(\text { Hari } \\
\text { ke 30) }\end{array}$ \\
\hline $\begin{array}{l}\text { Non- } \\
\text { vakum } \\
(\mathrm{cfu} / \mathrm{g})\end{array}$ & $3,50 \times 10^{6}$ & $3,15 \times 10^{6}$ & $3,08 \times 10^{6}$ \\
$\begin{array}{l}\text { Vakum } \\
(\mathrm{cfu} / \mathrm{g})\end{array}$ & $8,0 \times 10^{5}$ & 0 & 0 \\
\hline
\end{tabular}

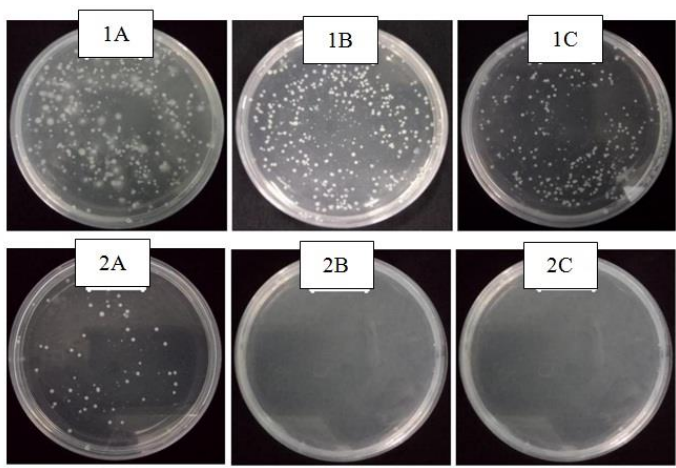

Gambar 1. Hasil pengujian TPC pada sampel ikan asap
Keterangan:

1A: non-vakum suhu ruang; 1B: non-vakum suhu dingin; 1C: non-vakum suhu beku. 2A: vakum suhu ruang, $2 \mathrm{~B}$ : vakum suhu dingin, 2C: vakum suhu beku.

Sampel ikan asap dilakukan pengujian mikrobiologi menggunakan metode Total Plate Count (TPC) dengan tiga kali pengulangan. Pengujian dilakukan pada hari ke 4, 6, dan 30 pada masing-masing sampel yang berbeda. Hasil pengujian menunjukkan penyimpanan dengan perlakukan kemasan vakum memiliki nilai TPC rendah. Pada perlakuan kemasan vakum suhu ruang nilai TPC sebesar $8,0 \times 10^{5} \mathrm{CFU} / \mathrm{gr}$, perlakuan kemasan vakum suhu dingin diperoleh nilai TPC sebesar 0 CFU/gr, dan perlakuan kemasan vakum suhu beku diperoleh nilai TPC sebesar 0 CFU/gr.

Nilai TPC pada produk ikan asap dengan perlakuan tanpa pengemasan vakum terlalu tinggi diduga karena proses pengasapan, penyimpanan, dan kondisi lingkungan sekitar. Pada kasus ini, mitra menggunakan pengasapan dengan metode konvesional yaitu menggunakan rak para-para dari besi untuk meletakkan ikan. Hal ini dapat memicu adanya bakteri yang mengkontaminasi produk ikan asap. Proses penjualan ikan asap yang diletakkan pada keranjang atau bak secara terbuka tanpa kemasan mengundang serangga dan lalat sehingga produk mudah terkontaminasi oleh mikroorganisme dari serangga tersebut.

Menurut hasil penelitian Angela et al. [7], menunjukkan pada produk yang dikemas vakum menunjukkan jumlah bakteri lebih rendah, hal ini kemungkinan disebabkan karena tidak tersedianya oksigen untuk kebutuhan metabolisme dari bakteri, sehingga menghampat pertumbuhan bakteri aerobik walaupun kadar air yang dikandung produk cukup untuk aktifitas bakteri.

Namun demikian, pada penyimpanan suhu ruang $\left(27{ }^{\circ} \mathrm{C}\right)$ selama empat hari baik dikemas vakum maupun tidak dikemas samasama tidak dapat memenuhi SNI. Penyimpanan pada suhu dingin $\left(4^{\circ} \mathrm{C}\right)$ selama enam hari dan suhu beku $\left(-20{ }^{\circ} \mathrm{C}\right)$ selama 30 hari untuk ikan asap yang dikemas vakum dapat memenuhi standar SNI, sedangkan yang tidak dikemas vakum tidak memenuhi standar SNI. Syarat mutu ikan asap yang 
direkomendasikan oleh Badan Standar Nasional Indonesia (SNI 2725:1:2009) adalah maksimum nilai TPC 1,0 x 105 koloni/g [8].

\section{Uji Organoleptik}

\section{Suhu ruang}

Nilai rata-rata organoleptik (kenampakan, baru, rasa dan tekstur) ikan asap yang dikemas vakum dan tidak dikemas vakum pada penyimpanan suhu ruang $\left(27^{\circ} \mathrm{C}\right)$ selama empat hari dapat dilihat pada Gambar 2. Nilai rata-rata organoleptik ikan asap yang dikemas vakum lebih baik dibanding yang tidak dikemas vakum. Hal ini disebabkan pada ikan yang dikemas vakum mikroorganisme aerob penyebab pembusukan sulit tumbuh sehingga kualitas ikan asap dapat bertahan lebih lama.

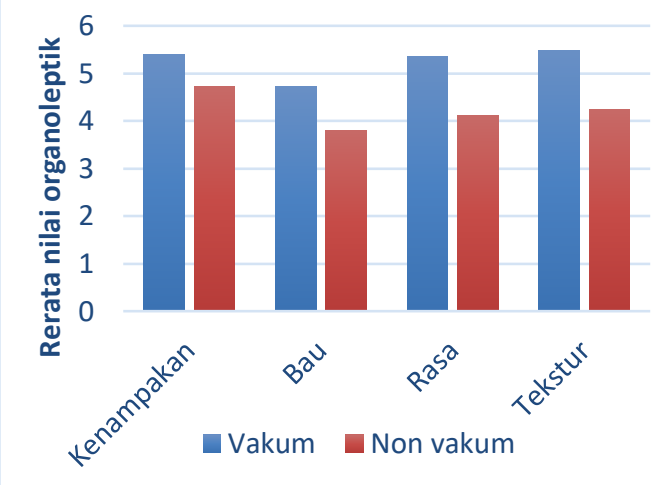

Gambar 2. Rerata organoletik ikan asap yang disimpan pada suhu ruang

Hasil pengujian hedonik pada metode pengemasan berbeda menunjukkan perbedaan yang signifikan terhadap nilai organoleptik yang disimpan pada suhu ruang $(\mathrm{P}<0,05)$. Hal ini menunjukkan bahwa panelis lebih menyukai ikan asap yang dikemas vakum.

Kaiang et al. [9] menyatakan bahwa semakin lama waktu penyimpanan menyebabkan nilai organoleptik dari segi kenampakan semakin menurun. Hal ini disebabkan hampir seluruh bagian tubuh ikan sudah ditumbuhi oleh jamur sehingga sudah tidak layak lagi. Kemasan vakum dapat mencegah tumbuhnya jamur. Sedangkan dari segi rasa lama penyimpanan dapat mengubah cita rasa sebagai akibat perubahan karakter fisikokimia sehingga secara organoleptik ditolak oleh konsumen. Dengan mempertimbangkan semua parameter organoleptik pada penyimpanan suhu ruang, panelis lebih menyukai produk ikan asap utuh yang dikemas vakum dan tidak dikemas vakum pada penyimpanan 0 hari.

\section{Suhu dingin}

Nilai rata-rata organoleptik (kenampakan, baru, rasa dan tekstur) ikan asap yang dikemas vakum dan tidak dikemas vakum pada penyimpanan suhu dingin $\left(4^{\circ} \mathrm{C}\right)$ selama enam hari dapat dilihat pada Gambar 3. Nilai rata-rata organoletik ikan asap yang dikemas vakum lebih baik dibanding yang tidak dikemas vakum. Hal ini disebabkan kemasan vakum dapat menghambat pertumbuhan mikroorganisme. Suhu dingin diketahui juga dapat menghambat pertumbuhan mikroorganisme. Sehingga jika dibandingkan dengan penyimpanan suhu ruang, penyimpanan suhu dingin memiliki kualitas organoleptik yang lebih baik.

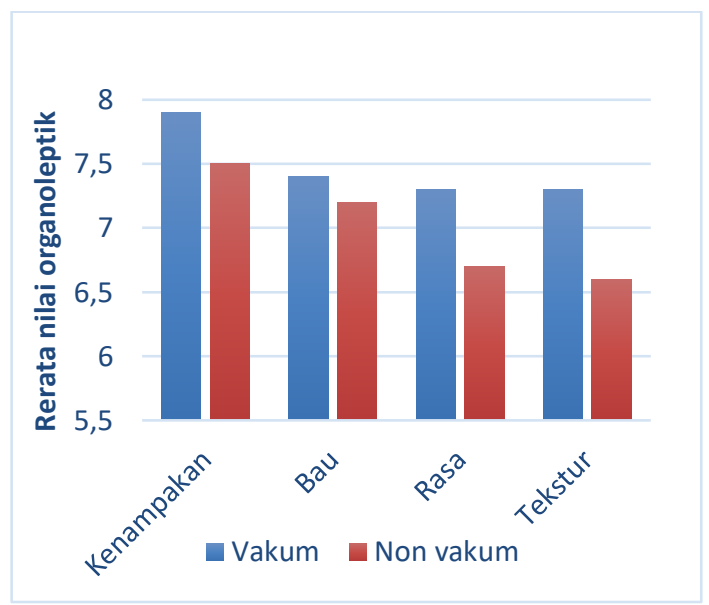

Gambar 3. Rerata organoletik ikan asap yang disimpan pada suhu dingin

Hasil pengujian hedonik pada metode pengemasan berbeda menunjukkan perbedaan yang signifikan terhadap nilai organoleptik ikan asap yang disimpan pada suhu dingin $(\mathrm{P}<0,05)$. Hal ini menunjukkan bahwa panelis lebih menyukai ikan asap yang dikemas vakum.

Angela et al. [7] menyatakan kehadiran mikroorganisme pada ikan juga mengakibatkan perubahan bau. Bau tersebut timbul akibat timbulnya amoniak $\left(\mathrm{NH}_{3}\right)$ pada degradasi protein dan gas $\mathrm{H}_{2} \mathrm{~S}$ pada degradasi protein yang mengandung unsur sulfur oleh 
bakteri pembentuk gas $\mathrm{H}_{2} \mathrm{~S}$. Parameter bau menunjukkan bahwa ikan kembung asap dengan kemasan vakum memperoleh nilai tertinggi sedangkan ikan kembung asap dengan perlakuan tanpa pengemas dinilai paling rendah oleh panelis. Berdasarkan penilaian panelis nilai bau terbaik adalah produk yang dikemas vakum dengan lama penyimpanan tujuh hari, yaitu bau asap masih tercium dan produk masih baik.

\section{Suhu beku}

Nilai rata-rata organoleptik (kenampakan, baru, rasa dan tekstur) ikan asap yang dikemas vakum dan tidak dikemas vakum pada penyimpanan suhu beku $\left(-20^{\circ} \mathrm{C}\right)$ selama 30 hari dapat dilihat pada Gambar 4. Nilai rata-rata organoletik ikan asap yang dikemas vakum lebih baik dibanding yang dikemas non vakum. Suhu beku membuat mikroorganisme semakin sulit tumbuh sehingga ikan asap dapat bertahan pada kondisi relatif baik hingga 30 hari.

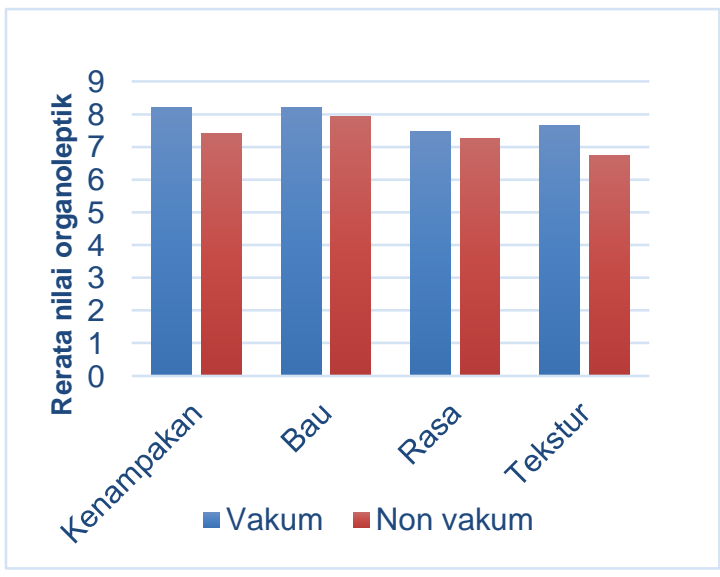

Gambar 4. Rerata organoletik ikan asap yang disimpan pada suhu beku

Hasil pengujian hedonik pada metode pengemasan berbeda menunjukkan perbedaan yang signifikan terhadap nilai organoleptik ikan asap yang disimpan pada suhu beku $(\mathrm{P}<0,05)$. Hal ini menunjukkan bahwa panelis lebih menyukai ikan asap yang dikemas vakum.

Aktivitas bakteri maupun enzimatis mengakibatkan degradasi jaringan pengikat yang menyebabkan penurunan nilai tekstur sehingga menjadi lunak. Mikroba yang ada menghasilkan benang-benang jamur dan lendir-lendir yang membuat nilai bau, tekstur dan penampakan semakin rendah [7]. Berdasarkan penilaian panelis, parameter tekstur masih dalam kriteria yang baik adalah produk yang dikemas vakum dengan lama penyimpanan sampai tujuh hari dan produk yang tidak dikemas vakum hanya sampai penyimpanan 0 hari masih disukai panelis.

\section{KESIMPULAN}

Hasil pengujian TPC dan organoleptik produk ikan asap menunjukkan bahwa produk ikan asap yang dikemas menggunakan kemasan vakum memiliki nilai TPC lebih rendah dan bisa diterima oleh konsumen. Teknologi pengemasan vakum dapat mempertahankan kualitas ikan asap sehingga diharapkan dapat meningkatkan nilai jual ikan asap. Saran bagi konsumen adalah jika ikan asap yang telah dikemas vakum tidak segera diolah maka sebaiknya disimpan dalam suhu dingin atau beku untuk tetap mempertahankan kualitasnya.

\section{UCAPAN TERIMAKASIH}

Ucapan terimakasih kepada LPPM Universitas Brawijaya yang telah memberikan dukungan dana melalui program Doktor Mengabdi 2019 (Nomor DIPA 042.01.2.400919/2019), Dinas Perikanan dan Peternakan Kab. Tuban, dan para penjual ikan asap terutama Ibu Temok dan Ibu Nur Lina yang telah bersedia menjadi mitra pada kegiatan ini.

\section{DAFTAR PUSTAKA}

[1] BPS Jawa Timur. 2018. Produksi Perikanan Budidaya dan Tangkap Perikanan Laut Menurut Kabupaten/Kota di Jawa Timur (Ton), 2010-2017. https://jatim.bps.go.id/statictable/2018/1 1/14/1417/produksi-perikanan-tangkapperikanan-laut-menurut-kabupaten-kotadi-jawa-timur-ton-2010-2017.html

[2] BPS Kabupaten Tuban. 2018. Produksi Perikanan Budidaya dan Tangkap Perikanan Laut Kabupaten Tuban (Ton), 2010-2017. https://tubankab.bps.go.id/ 
[3] Mareta, D.T. \& Awami, S.N., 2011. Pengawetan Ikan Bawal dengan Pengasapan dan Pemanggangan. Mediagro, 7(2), pp.33-47. Available at: http://unwahas.ac.id/ publikasiilmiah/index.php/Mediagro/ article/viewFile/532/654.

[4] Tutuarima, T., 2016. No Title. Agroindustri, 6 (1), pp.28-33. Available at: http:// repository.unib.ac.id/11656/1/ JURNAL AGROINDUSTRI.pdf.

[5] Hadi, J dan L. Widawati. 2015. Analisis Sanitasi dan Cemaran Mikroorganisme Ikan Asap Lele Di Bengkulu. AGRITEPA 2 (1), hal: 57-68

[6] Standard Nasional Indonesia (SNI). 2009. Ikan Asap Bagian 1. Spesifikasi. SNI 27 25.1:2009. Badan Standardisasi Nasional. Jakarta.

[7] Angela, G.C., F. Mentang dan G. Sanger. 2015. Kajian mutu ikan cakalang (Katsuwonus pelamis, 1.) asap dari tempat pengasapan desa girian atas yang dikemas vakum dan non vakum selama penyimpanan dingin. Jurnal Media Teknologi Hasil Perikanan. 3(2): 29 40.

[8] Badan Standar Nasional Indonesia (SNI 2725:1:2009)

[9] Kaiang, D.B, L.A.D.Y. Montolalu dan R.I. Montolalu. 2016. Kajian mutu ikan tongkol (Euthynnus affinis) asap utuh yang dikemas vakum dan non vakum selama 2 hari penyimpanan pada suhu kamar. Jurnal Media Teknologi Hasil Perikanan. 4(2): 75 - 84 . 